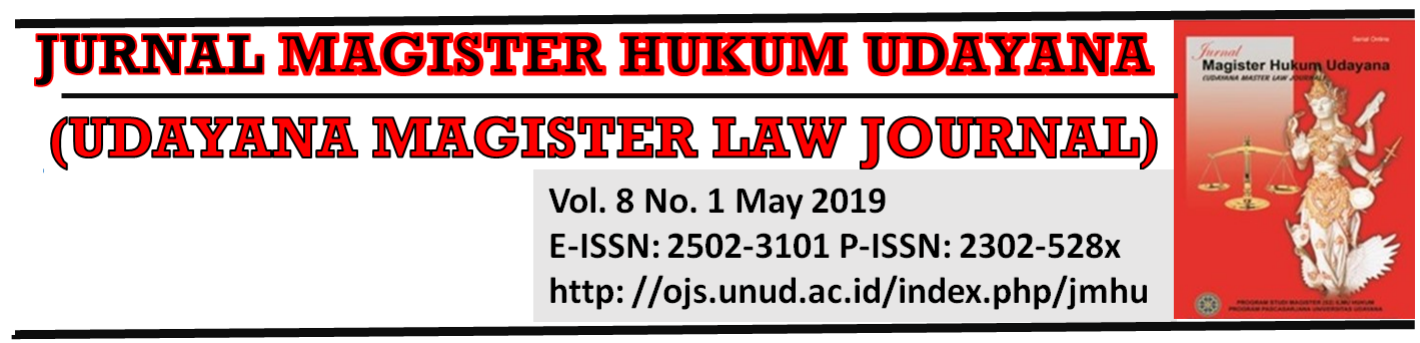

\title{
Legal Protection For Children Against Online Sexual Exploitation and abuse of Children
}

\author{
Ni Putu Ika Wijakusumariasih ${ }^{1}$ \\ 1Singaraja District Court, Bali-Indonesia, E-mail: mommydanis@yahoo.com
}

\begin{tabular}{l}
\hline Info Article \\
\hline Received: $4^{\text {th }}$ March 2019 \\
Accepted: 29th May 2019 \\
Published: 31' May 2019 \\
Keywords: \\
Online pedophiles; Official \\
Candy's Group; Child \\
Protection \\
Corresponding Author: \\
Ni Putu Ika Wijakusumariasih, \\
E-mail: \\
mommydanis@yahoo.com \\
DOI: \\
10.24843/JMHU.2019.v08.i01. \\
p01
\end{tabular}

\begin{tabular}{l} 
Abstract \\
\hline The disclosure of cases of pedophiles online on social media in \\
Indonesia certainly dangers that lurk children from perpetrators \\
of sexual crimes. End Child Prostitution in Asian Tourism \\
(ECPAT) Indonesia and the Criminal Crime Reform Institute \\
(ICJR) regard this case of online child pornography as the largest \\
ever disclosed by police without casualties. Online pedophile \\
actors operating on social media Facebook use Official Candy \\
Group accounts. Online pedophile prostitution has involved \\
international networks. Departing from this background, the \\
purpose of writing this scientific paper is to find out about the \\
protection of children in Indonesia in terms of online pedophiles \\
that refer to international child protection instruments that have \\
been ratified. The research method used in this study is a \\
normative legal research method. Seeing the situation in the \\
territory of Indonesia become a place of practice that deviates \\
until the involvement of international syndicates and modes is \\
more sophisticated. Conditions further strengthen the assumption \\
that Indonesia is indeed in an emergency of sexual violence. \\
Harmonizing national laws to protect children online with \\
international standards is key to providing the right tools for law \\
enforcement in dealing with child sex crimes. In the child \\
protection survey in the digital era in ASEAN member countries, \\
it appears that Indonesia still needs improvement in terms of legal \\
instruments related to child protection in the context of \\
regulations and policies in making child protection mechanisms \\
in the virtual realm in accordance with global commitments in \\
which Indonesia is member of several international organizations. \\
\hline
\end{tabular}

\section{Introduction}

Indonesia emergency child sexual violence behavior because the number of cases of sexual violence that occur in children in Indonesia is increasing and varied and the case is also very complex. Conditions further strengthen the assumption that Indonesia is indeed in an emergency state of sexual violence. One of the main causes of the increasing number of cases of sexual violence against children is easier access to pornography in cyberspace, with thousands of sites deliberately offered and presented to anyone and anywhere. ${ }^{1}$ As pointed out by Taylor and Quayle (2003), the legal definition of child pornography does not capture all the material that an adult with a

1 Kartiko, G. (2013). Pengaturan Terhadap Yurisdiksi Cyber Crime Ditinjau dari Hukum Internasional. Rechtidee, 8(2), 136-153. 
sexual interest in children may consider sexualized or sexual. As they argue, understanding why child pornography is produced and collected requires us to think beyond the legal definition of child pornography. ${ }^{2}$

The rise of cybercrime is due to the emergence of the internet now likened to a new border area. Cybercrime in the strict sense is computer crime which refers to a computer system or network, while in the world of cybercrime it covers all forms used for computers, computer networks, and users and traditional forms that are carried out using or with the help of computers (Computer-related crimes). ${ }^{3}$ This new area is free to be exploited and explored without any law regulating it. One of the major difficulties in dealing with the problem of cybercrime is its very transboundary nature. Almost knows no national boundaries. Cybercrime in one country can be carried out from and through any other country in the world, can determine its victims in any part of the world, can hide the identity of the perpetrator through a computer system located in any country.

Based on internet world stats usage and population statistic, Indonesia is known to be in the third largest position of the 35 highest internets and facebook user countries in Asia in articles published on Internet World Stats. ${ }^{4}$

Table 1 ASIA Internet Use, Population Data and Facebook Statistics - December 2017

\begin{tabular}{|c|c|c|c|c|c|c|}
\hline$\underline{\text { ASIA }}$ & $\begin{array}{l}\text { Population } \\
\text { ( } 2018 \text { Est.) }\end{array}$ & $\begin{array}{c}\text { Internet } \\
\text { Users, } \\
\text { (Year 2000) }\end{array}$ & $\begin{array}{l}\text { Internet Users } \\
\text { 31-Dec-2017 }\end{array}$ & $\begin{array}{l}\text { Penetration } \\
\text { (\% Population) }\end{array}$ & $\begin{array}{l}\text { Users } \\
\% \text { Asia }\end{array}$ & $\begin{array}{c}\text { Facebook } \\
\text { 31-Dec-2017 }\end{array}$ \\
\hline Afganistan & $36,373,176$ & 1,000 & $5,700,905$ & $15.7 \%$ & $0.3 \%$ & $3,200,000$ \\
\hline Armenia & $2,934,152$ & 30,000 & $2,126,716$ & $72.5 \%$ & $0.1 \%$ & 990,000 \\
\hline Azerbaijan & $9,923,914$ & 12,000 & $7,999,431$ & $80.6 \%$ & $0.4 \%$ & $1,800,000$ \\
\hline Bangladesh & $166,368,149$ & 100,000 & $80,483,000$ & $48.4 \%$ & $3.8 \%$ & $28,000,000$ \\
\hline Bhutan & 817,054 & 500 & 370,423 & $45.3 \%$ & $0.0 \%$ & 350,000 \\
\hline $\begin{array}{l}\text { Brunei } \\
\text { Darussalam }\end{array}$ & 434,076 & 30,000 & 410,836 & $94.6 \%$ & $0.0 \%$ & 350,000 \\
\hline Cambodia & $16,245,729$ & 6,000 & $8,005,551$ & $49.3 \%$ & $0.4 \%$ & $6,300,000$ \\
\hline China ${ }^{*}$ & $1,415,045,928$ & $22,500,000$ & $772,000,000$ & $54.6 \%$ & $38.1 \%$ & $1,800,000$ \\
\hline Georgia & $3,907,131$ & 20,000 & $2,658,311$ & $68.0 \%$ & $0.1 \%$ & $2,100,000$ \\
\hline Hong Kong * & $7,428,887$ & $2,283,000$ & $6,461,894$ & $87.0 \%$ & $0.3 \%$ & $5,200,000$ \\
\hline India & $1,354,051,854$ & $5,000,000$ & $462,124,989$ & $34.1 \%$ & $22.8 \%$ & $251,000,000$ \\
\hline$\underline{\text { Indonesia }}$ & $266,794,980$ & $2,000,000$ & $143,260,000$ & $53.7 \%$ & $7.1 \%$ & $130,000,000$ \\
\hline Japan & $127,185,332$ & $47,080,000$ & $118,626,672$ & $93.3 \%$ & $5.9 \%$ & $71,000,000$ \\
\hline Kazakhstan & $18,403,860$ & 70,000 & $14,063,513$ & $76.4 \%$ & $0.7 \%$ & $2,500,000$ \\
\hline Korea, North & $25,610,672$ & - & 20,000 & $0.0 \%$ & $0.0 \%$ & 14,000 \\
\hline
\end{tabular}

2 Krone, T. (2004). A typology of online child pornography offending. Canberra: Australian Institute of Criminology..h.1

3 Tianotak, N. (2011). Urgensi Cyberlaw Di Indonesia Dalam Rangka Penangan Cybercrime Disektor Perbanka. Jurnal Sasi, 17(4). h.20

4 Internet World Stats Usage And Population Statistic Retrieved from https://www.internetworldstats.com/stats3.html 


\begin{tabular}{|c|c|c|c|c|c|c|}
\hline Korea, South & $51,164,435$ & $19,040,000$ & $47,353,649$ & $92.6 \%$ & $2.3 \%$ & $43,000,000$ \\
\hline Kyrgystan & $6,132,932$ & 51,600 & $2,493,400$ & $40.7 \%$ & $0.1 \%$ & 650,000 \\
\hline$\underline{\text { Laos }}$ & $6,961,210$ & 6,000 & $2,439,106$ & $35.0 \%$ & $0.1 \%$ & $2,200,000$ \\
\hline Macao ${ }^{*}$ & 632,418 & 60,000 & 512,352 & $81.0 \%$ & $0.0 \%$ & 380,000 \\
\hline Malaysia & $32,042,458$ & $3,700,000$ & $25,084,255$ & $78.3 \%$ & $1.2 \%$ & $22,000,000$ \\
\hline$\underline{\text { Maldives }}$ & 444,259 & 6,000 & 340,000 & $76.5 \%$ & $0.0 \%$ & 320,000 \\
\hline Mongolia & $3,121,772$ & 30,000 & $2,000,000$ & $64.1 \%$ & $0.1 \%$ & $1,900,000$ \\
\hline Myanmar & $53,855,735$ & 1,000 & $18,000,000$ & $33.4 \%$ & $0.9 \%$ & $16,000,000$ \\
\hline Nepal & $29,624,035$ & 50,000 & $16,190,000$ & $54.7 \%$ & $0.8 \%$ & $8,700,000$ \\
\hline Pakistan & $200,813,818$ & 133,900 & $44,608,065$ & $22.2 \%$ & $2.2 \%$ & $32,000,000$ \\
\hline Philippines & $106,512,074$ & $2,000,000$ & $67,000,000$ & $62.9 \%$ & $3.3 \%$ & $62,000,000$ \\
\hline Singapore & $5,791,901$ & $1,200,000$ & $4,839,204$ & $83.6 \%$ & $0.2 \%$ & $4,300,000$ \\
\hline Sri Lanka & $20,950,041$ & 121,500 & $6,710,160$ & $32.0 \%$ & $0.3 \%$ & $5,500,000$ \\
\hline Taiwan & $23,694,089$ & $6,260,000$ & $20,821,364$ & $87.9 \%$ & $1.0 \%$ & $18,000,000$ \\
\hline Tajikistan & $9,107,211$ & 2,000 & $3,013,256$ & $33.1 \%$ & $0.1 \%$ & 170,000 \\
\hline Thailand & $69,183,173$ & $2,300,000$ & $57,000,000$ & $82.4 \%$ & $2.8 \%$ & $46,000,000$ \\
\hline Timor-Leste & $1,324,094$ & 0 & 410,000 & $31.0 \%$ & $0.0 \%$ & 390,000 \\
\hline Turkmenistan & $5,851,466$ & 2,000 & $1,049,915$ & $17.9 \%$ & $0.1 \%$ & 20,000 \\
\hline Uzbekistan & $32,364,996$ & 7,500 & $15,453,227$ & $47.7 \%$ & $0.8 \%$ & 800,000 \\
\hline Vietnam & $96,491,146$ & 200,000 & $64,000,000$ & $66.3 \%$ & $3.2 \%$ & $50,000,000$ \\
\hline TOTAL ASIA & $4,207,588,157$ & $114,304,000$ & $2,023,630,194$ & $48.1 \%$ & $100.0 \%$ & $818,934,000$ \\
\hline
\end{tabular}

Source: Internet World Stats Usage And Population Statistic URL

Data at the international level states that in different age categories, children show different interests and activities in internet usage, based on the context of their age. However, data shows that children start using the internet at an increasingly young age. This can increase the ease of sexual exploitation of children as revealed in the case of online pedophiles in the Official Candy's Group account which can be categorized as extraordinary crimes. The phenomenon of loly candy is a necessity in the cyberspace, where there is a relationship between the criminal act of pornography and sexual crime. ${ }^{5}$ Pedophilia According to the Criminal Code In the Criminal Code (KUHP), an act known as pedophilia is an obscene act committed by an adult with an underage. Quoting the KUHP book As well as the comments by R. Soesilo, the term obscene conduct is explained as an act that violates the sense of decency, or other acts that are cruel, and all in the environment of sexual desire. For example, kissing, groping the genitals, groping breasts, etc .; including intercourse, but in the law, itself is stated ${ }^{6}$

The official Loli Candy's Group is a pedophile group that is estimated to spread thousands of photos and videos of sexual violence against children on their Facebook accounts. The Facebook account is then connected to the WhatsApp group and the

5 Sulistyo, F., \& Manap, N. A. (2018). Pornography and Sexual Crimes towards Children in Indonesia: A Judicial Approach. Brawijaya Law Journal, 5(2), 261-270.,h.262.

6 Soesilo, R. (1991). Kitab Undang-Undang Hukum Pidana serta Komentarnya Pasal demi Pasal. Bogor: Politea, h.212. 
international Telegram consists of a number of men from several Latin American states suspected of being pedophiles. Before 2017, cases of online child prostitution had already occurred but now the cases revealed are more complexes reaching the virtual world by involving international networks in the name of the perpetrators not only adults but some perpetrators of children.

The development of pedophile cases from the previous year up to the last two years has increased, where the predator of this child is increasingly rampant and does not feel deterred even doing prostitution online in cyberspace. The law apparatus ensnares online pedophiles in the Official Loli Candy's Group group account with a multi-layered article with the Child Protection Act, ITE Law and Pornography Law. Regarding the legal protection system for victims of online pedophiles, Indonesian law enforcement officials must solve the problem of sexual violence and online pornography refers to global commitments as a basic guideline. UNICEF defines a child protection system as a set of laws and regulations to support the prevention and management of risks related to child protection. Meanwhile, there are other institutions namely End Prostitution in Asian Tourism (ECPAT) which can also be a guideline for child protection in cyberspace for Indonesia. ECPAT is a global network organization and individuals working together to eliminate child prostitution, child pornography and the trafficking of children for sexual purposes. ECPAT seeks to encourage the world community to ensure that children everywhere must be able to enjoy their basic rights and feel safe from all forms of commercial sexual exploitation. ${ }^{7}$ Another guideline that becomes a reference for child protection in cyberspace for Indonesia is the ASEAN Conference on Working Towards a Cyber Pornography and Cyber Prostitution Free Southeast Asia. This conference gave birth to four important recommendations in anticipation of discussing issues related to pornography and child prostitution in cyberspace across countries, especially through strong telecommunications cooperation and regulation among ASEAN countries. This effort is supported by the presence of the CERT (Computer Emergency Response Team). Nine out of 10 ASEAN member countries, including Indonesia, already have CERT (http://www.cert.or.id). CERT is a team that has a significant duty as cyber police to secure cyberspace at the national level by building a network consisting of IT experts. In addition, there are child protection instruments, rules, and policies at the international level that have been ratified.

Indonesia has to establish a system of child protection mechanisms in the virtual domain. However, from year to year, online pedophile crime is still occurring even though the mode is increasingly complex and sophisticated. In the child protection survey in the digital era in ASEAN member countries, law enforcement devices related to child protection in the virtual domain, the survey data shows that Indonesia still has a lot of room for improvement in terms of legal instruments related to child protection. ${ }^{8}$ Just as criminalization has not been maximized in national legislation regarding all actions relating to child abuse, images include approaching children online for grooming as a standard in international commitments. Harmonization of national laws to protect

7 Rafiqa, A. L., \& Rani, F. (2015). Peran End Child Prostitution, Child Pornography and Trafficking of Children for Sexual Purposes (Ecpat) Internasional dalam Menanggulangi Kasus Child Trafficking di Albania (2007-2012). International Society, 2(2), h.15

8 Triastuti Endah,dkk,2017, Peta Jalan Perlindungan Anak Indonesia Di Internet (Sebuah Pengantar), h. 20 
children online with international standards is the key to providing the right tools for law enforcement in overcoming crime.

Previous research also examined pedophile crime, but the focus was different including research conducted by Anak Agung Ayu Sinta Paramita Sari who reviewed "Criminal Responsibility and Criminalization Against Pedophile Actors in Indonesian Criminal Law," the study focused more on the issue of criminalization of perpetrators pedophilia. In addition, Rahmi Adam Yuriswanto who reviewed the "Castration Punishment as an Additional Crime in the Crime of Sexual Crime" but with an emphasis on the implementation of castration penalties in sexual crimes. Meanwhile, in this paper, the focus of the study is to examine the regulation of the system of child protection in cyberspace from the sexual exploitation of online pedophiles based on the basic guidelines of international commitments related to child protection.

\section{Research Methods}

The research method used in this study is a normative legal research method and the object of research is the norm system. The norm system in question is regarding principles, norms, rules of law and regulations, court decisions, treaties, and doctrines. ${ }^{9}$ In this study writing the approach used is the statue approach, which is carried out by examining the issues discussed using applicable legislation and the conceptual approach, which is carried out by analyzing theories, concepts, and relevant principles with the problems of this study.

\section{Results and Discussion}

\subsection{Juridical foundation for child protection in Indonesia}

Child protection is an important concern for the Indonesian government after intensively various forms of sexual violence against children in Indonesia were raised to the surface by various groups. Sexual violence against children such as online pornography, online child pornography, online child prostitution, pornographic compact disk objects and children victims of online sexual violence. Similar phenomena also arise in various other Asian regions, such as in the Philippines, Thailand, Vietnam and in other developed countries, so that this issue quickly becomes regional and even global which raises concerns for the world community about the importance of this problem. Pedophiles are one of the most sophisticated and complex forms of a sexual crime against children by using the internet as a means to commit crimes so that they need the role of the state to cooperate with the international world. Goldstein in his article entitled International Relations, the role of the state can be the most important actor in international relations, but in fact, their role is very dependent, limited and influenced by non-state actors including individuals, inter-state organizations, nongovernmental international organizations, movements religion, multinational companies, and etc. ${ }^{10}$

9 Dewata, M. F. N., \& Achmad, Y. (2010). Dualisme Penelitian Hukum Normatif dan Empiris. Yogyakarta: Pustaka Pelajar, h. 34.

10 Millatina, A. H., \& Hanura, M. (2018). Peran ECPAT dalam Menangani Eksploitasi Seksual Komersial Anak di Indonesia. Journal of International Relations, 4(3), .h.6 
Ensuring the protection of internet access for children and adolescents is a challenge at the global level. Some countries in the world such as Ghana, Kenya, Japan and Singapore, America has policies and rules to reduce the risk of children and adolescents when accessing the internet. ITU (International Telecommunications Union) has developed a set of directives that can be adopted at the global level for children, parents/guardians/ educational institutions, industry, civil society, government, civil society, and non-profit organizations. In Indonesia, the role of child protection is specifically under the Ministry of Women's Empowerment and Child Protection. In addition, the role of child protection is also under the Coordinating Ministry for Human Development and Culture in coordination with the national task force on anti-trafficking crimes (TPPO) and Cyber Anti-Narcotics and Radicalism Team of the Ministry of Religion. Online child protection is an important subject for agencies in this agency. The review focused on the evaluation of research findings, which considered individual and organizational factors associated with resilience or burnout in child protection social work staff. ${ }^{11}$

Specifically, in Indonesia, there are several legal bases in child protection in cyberspace, namely based on a juridical foundation, as well as national and operational strategies. Legal instruments in Indonesia have fulfilled the elements of law enforcement, namely regulatory elements, law enforcement officers and facilities but have not been maximized. For example, the investigative mechanism requires special methods, but the procedural law has not provided guidance on this matter. Another aspect is the law of proof of crime online child sexual abuse/exploitation requires a burden of proof that is not easy, therefore many cases fail to be brought to court because of the lack of evidence. Different justice systems include the perspective of judges in judging or punishing these perpetrators. Portrait of law enforcement agencies, especially the police, who do not all have cyber units. Some countries already have it but have not focused on online crime child sexual abuse/exploitation but for certain crimes (terrorism, people smuggling/trafficking in persons). Another aspect is uneven expertise between law enforcers and high turnover that causes law enforcement to not focus on dealing with this problem. Child protection in cyberspace can refer to a juridical foundation including:

1. 1945 Constitution, 4 th Amendment Article 28b

2. Law of the Republic of Indonesia Number 1 of 1974 concerning Marriage

3. Law of the Republic of Indonesia Number 4 of 1979 concerning Child Welfare

4. Law of the Republic of Indonesia Number 39 of 1999 concerning Human Rights

5. Republic of Indonesia Law Number 35 of 2014 concerning Amendments to the Law of the Republic of Indonesia Number 23 of 2002 concerning Child Protection

6. Law of the Republic of Indonesia Number 13 of 2003 concerning Labor

7. Law of the Republic of Indonesia Number 20 of 2003 concerning the National Education System

8. Law of the Republic of Indonesia Number 21 of 2007 concerning Crime of Trafficking in Persons

9. Law of the Republic of Indonesia Number 44 of 2008 concerning Pornography

11 McFadden, P., Campbell, A., \& Taylor, B. (2014). Resilience and burnout in child protection social work: Individual and organisational themes from a systematic literature review. The British Journal of Social Work, 45(5), .h.1549 
10. Law of the Republic of Indonesia Number 36 of 2009 concerning Health

11. Republic of Indonesia Law Number 11 of 2012 concerning Child Criminal Justice System

12. Law of the Republic of Indonesia Number 19 the Year 2016 concerning Amendments to Law Number 11 the Year 2008 concerning Information and Electronic Transactions

13. Law of the Republic of Indonesia Number 10 of 2012 concerning Ratification of the Optional Protocol To The Convention on the Rights of the Child on the Sale of Children, Child Prostitution and Child Pornography (Optional Protocol to the Convention on the Rights of the Child Regarding the Sale of Children, Child Prostitution, and Child Pornography)

It is important for the state to harmonize legal / legal frameworks to fight cybercrime, protect the penetration of online/online children and facilitate international cooperation. Why need to be harmonized because the development of the quantity, quality, intensity and operandi mode of cyberpornography has international implications so that prevention and mitigation efforts must be carried out through international cooperation. This is consistent with the characteristics of cyberpornography that is transnational.

Harmonization of national laws to protect children online with international standards is the key to providing the right tools for law enforcement in overcoming crime. This is a monopoly from the authorities. Max Weber in the theory of coercion (dwang theory) suggests that the ruler has a monopoly on the physical means of coercion which are the basis for the purpose of the law to achieve order and order, coercion is intended only by groups of people who have the authority to do so. (in this case such as the police, prosecutor's office, or court). ${ }^{12}$

\subsection{Legal protection against sexual exploitation of children in cyberspace}

The Central Statistics Agency (BPS) and the National Development Planning Agency (Bappenas) estimate that currently the Indonesian population aged between 10-19 years is as many as 45 million people and those who are often referred to as part of the Z generation, or post-millennial generation, they born in the range of 1995 to 2012. Generation $\mathrm{Z}$ is actually also part of the young generation of digital natives, namely those who were born in the cyber era with various aspects of life served and influenced by online behavior and the existence of internet access. The negative impact of the progress of the electronic media revolution has resulted in the weakening of kinship networks of large families and societies that are manifested in new phenomena such as the emergence of vulnerable or marginal groups. Non-legal policies that can be used to prevent illegal actions that can damage children through government-sponsored online media and the information and communication technology sector to open the views of children and adolescents through direct consultation or through research, and try into policies and a program to ward off online sexual abuse. Information and communication technology companies working with legal authorities create a secure internet environment. Parents and guardians of children to talk with children about internet safety, ensure children understand internet issues. Teachers like social tools

12 Dirdjosisworo, S. (1983). Pengantar tentang psikologi hukum. Bandung: Alumni. h.73 
and internet platforms lend hope on the internet. Schools can provide information about digital security or internet literacy in the school curriculum. Children and adolescents to actively support each other by sharing information about how to protect each other and fight the internet by understanding will provide many things and opportunities that can be obtained in the internet world. For example, online pedophile cases which can be said as cases of extraordinary crime because the victims are children. Loly Candy's Group 18+ 1 Loly Candy's Group 18+ official group has been uplifting lately, using the internet as the main medium to share their pleasures. In this group consists of thousands of group members and hundreds of videos and photos about child pornography that is not only from within the country but is an international network of pedophiles. It is unfortunate that the perpetrators in this group are not only adults but also children. They are united, in a social media container, in this case utilizing the Facebook platform. The Internet has become the main medium in distribution, especially digital products. Pornographic content on the internet is also a digital product. It is easily distributed through the internet. These crimes can be said to be extraordinary crimes so that law enforcement officials must provide legal protection for children and adolescents with reference to international standards. Beside Loly Candy's Group there are another case such as online pornography by $28 \%$, online child pornography $21 \%$, online child prostitution $20 \%$, pornographic cd objects $15 \%$ and children victims of online sexual violence $11 \%$. This number is predicted to continue to increase if it is not addressed optimally, and this is the responsibility of all of us. ${ }^{13}$

Legal protection for children is an effort to protect various fundamental rights and freedom of children, as well as various interests related to child welfare. Legal protection for children covers a broad scope. In a state perspective, the state protects its citizens, including its children, can be found in the opening of the 1945 Constitution which is reflected in paragraph IV, in the description of CHAPTER XA concerning Human Rights, especially for the protection of children, Article 28B paragraph (2) The 1945 Constitution states that every child has the right to survival, growth and development, and has the right to protection from violence and discrimination. According to UNICEF, this child protection system is the responsibility of all orders including government agencies, by providing services at the level of local authorities, partners outside the government, and community groups. ${ }^{14}$ UNICEF is steadfast in its commitment to strengthening protection from sexual exploitation and abuse. UNICEF is working closely with the United Nations Sexual Exploitation and Abuse Working Group, the Inter-Agency Standing Committee Task Team on Accountability to Affected Populations and Protection from Sexual Exploitation and Abuse and other implementing partners to strengthen and scale up our programs to prevent and respond to sexual exploitation and abuse. ${ }^{15}$

13 Kementerian Perberdayaan Perempuan dan Perlindungan Anak Republik Indonesia. (2016). Press Release: Menteri PP dan PA : Indonesia Berkomitmen Hapuskan Kekerasan Seksual terhadap Anak Melalui Dunia Online. Retrieved from https://www.kemenpppa.go.id/index.php/page/read/29/115/press-release\%20menteripp-dan-pa-indonesia-berkomitmen-hapuskan-kekerasan-seksual-terhadap-anak-melaluidunia-online

14 Triastuti Endah,dkk,op.cit,h.3

15 UNICEF. (2017). UNICEF's approach to protection from sexual exploitation and abuse. Retrieved from https://www.unicef.org/protection/57929_96455.html 
The mechanism of child protection in cyberspace requires the existence of a national human rights institution (NHRI) equipped with a division that applies as a national child protection committee. Indonesia is the only ASEAN country that has an NHRI with a child protection division (child protection commission) namely the KPAI (Indonesian Child Protection Commission) which was formed based on Law Number 35 of 2014 concerning child protection.

The ASEAN Conference on Working Towards a Cyber Pornography and Cyber Prostitution Free Southeast Asia gave birth to four important recommendations in anticipation of discussing issues relating to pornography and child prostitution in cyberspace across countries in particular through strong telecommunication cooperation and regulation among ASEAN countries to create a world friendly and safe for children and women in the Southeast Asia region. This effort is supported by the existence of CERT (Computer Emergency Response Team), including Indonesia has had CERT as cyber police to secure cyberspace at the national level by building a network consisting of IT experts. In addition, there are at least five child protection instruments at the international level that should be ratified by a country to establish a system of child protection mechanisms in the virtual domain, in this case Indonesia has ratified the International Convention on the Rights of the Child (CRC), Choice of Protocol to the International Convention on the Rights of the Child on the sale of children, prostitution and child pornography, the ILO Convention on the worst forms of child labor, and ratify the Trafficking Protocol, while those that have not been ratified are the choice of international convention protocols, children's rights to communication procedures (optional protocol to the CRC on CRC procedures).

Regarding the reporting mechanism, the protection of children in cyberspace must be transparent, easily accessible and can be implemented or implemented by all parties including children. In this regard, UNICEF underlines that children and adolescents must feel safe and can feel this mechanism effectively. The mechanism must have legal validity, be accessible, predictable, fair, transparent, legitimate, uphold the right of a complaint mechanism, act as a place of learning that is sustainable, and based on relationships and dialogue. This reporting mechanism system must also provide adequate facilities if the rights of children are threatened. UNICEF added that it was important to note that girls, especially those from underprivileged families, often had difficulties accessing justice. The reporting system in child protection mechanisms also requires affirmative law enforcement tools for children and women and law enforcement agencies at the national level with members of staff capable of carrying out proactive and reactive activities focusing their investigations on victims and being able to work together at the international level. In the child protection survey in the digital era against ASEAN member countries, the survey data shows that Indonesia still has to improve in terms of legal instruments related to child protection. This can be seen from the proliferation of content that violates the law such as pornography to radicalism and the existence of online behavior that is not appropriate such as abuse to pedophilia is a serious threat to the safety of Indonesia's young generation on the Internet. At present there are several cases that are often reported about child activities in cyberspace online are:

1. Children who are victims of pornography from social media

2. Ownership of pornographic media

3. Victims of online and sexual violence 


\section{Online sex offenders}

In Indonesia, there are several legal foundations in child protection in cyberspace that are not sufficient in providing child protection in accordance with the United Nations Convention on the rights of children. Where this can be seen from the lack of clarity of the legal basis that defines precisely and clearly the content that abuses children (child abuse material) by including specific computer and internet terminology. A basic definition of content that misuses a child, visual representation or description of a child involved in an act or a real or simulated sexual appearance, or a false image. In addition, how technologies such as computers, the internet, cellphones, PDAs, games/games, video cameras, and DVDs can facilitate the content that abuses children, and make it clear that content that abuses children and anything related to them is illegal. All of these are provisions for online child protection that have not been implemented. In addition, there is no definition of online child abuse, clauses about obscenity and immorality and have not provided clear guidance for justice or law enforcement in dealing with crimes against children online. So that the harmonization of national laws to protect children online with international standards has not yet materialized.

\section{Conclusion}

The conclusions of this paper are as follows, Some of the Guidelines that serve as references for child protection in cyberspace for Indonesia include the general resolution of the UN council 68/167 of 2013 concerning the Right to privacy in the digital era without experiencing unlawful interference and UNICEF that defines a child protection system that requires coordination between sectors and levels, including routine referral systems, an important component of an effective child protection system. Another guideline that serves as a reference for child protection in cyberspace for Indonesia is the ASEAN Conference on Working Towards a Cyber Pornography and Cyber Prostitution Free Southeast Asia which discusses pornography and child prostitution in cross-country cyberspace through strong telecommunications cooperation and regulation among ASEAN countries.

The regulation of the system of child protection in cyberspace from the sexual exploitation of children online in the virtual domain has not been carried out optimally according to the basic guidelines of international commitments related to child protection. In many countries, the terminology often used in the context of criminal law is child pornography, although not all forms of crime fulfill the elements of child pornography, so there needs to be a reformulation of the form of crime in national criminal law. Make an investigation guide that can be carried out by law enforcement including guidance in obtaining strong evidence. Law enforcement skills still need to be improved and ensure that there is an institutional structure in law enforcement that is able to respond online to child sexual abuse/exploitation.

\section{Bibliography}

\section{Books}

Akdeniz, Y. (2016). Internet child pornography and the law: national and international responses. Routledge. 
Dewata, M. F. N., \& Achmad, Y. (2010). Dualisme Penelitian Hukum Normatif dan Empiris. Yogyakarta: Pustaka Pelajar.

Dirdjosisworo, S. (1983). Pengantar tentang psikologi hukum. Bandung: Alumni.

Krone, T. (2004). A typology of online child pornography offending. Canberra: Australian Institute of Criminology.

Livingstone, S., \& Haddon, L. (Eds.). (2012). Children, risk and safety on the Internet: Research and policy challenges in comparative perspective. Policy Press.

Maskun. (2013). Kejahatan Siber (Cyber Crime), Kencana.

Schjolberg, J. S., \& Hubbard, A. M. (2005). Harmonizing National Legal Approaches on Cybercrime. International Telecommunication Union (1 July 2005), 6.

Triastuti Endah,dkk. (2017). Peta Jalan Perlindungan Anak Indonesia Di Internet (Sebuah Pengantar).

Zainuddin, A. (2006). Filsafat Hukum. jakarta: Sinar Grafika

\section{Journal}

Harahap, I. S. (2016). Perlindungan Hukum Terhadap Anak Korban Kejahatan Seksual dalam Perspektif Hukum Progresif. Media Hukum, 23(1),37-47. https://doi.org/10.18196/jmh.2015.0066.37-47

Kartiko, G. (2013). Pengaturan Terhadap Yurisdiksi Cyber Crime Ditinjau dari Hukum Internasional. Rechtidee, 8(2), 136-153. http://dx.doi.org/10.21107/ri.v8i2.695

McFadden, P., Campbell, A., \& Taylor, B. (2014). Resilience and burnout in child protection social work: Individual and organisational themes from a systematic literature review. The British Journal of Social Work, 45(5), 1546-1563. https://doi.org/10.1093/bjsw/bct210

Millatina, A. H., \& Hanura, M. (2018). Peran ECPAT dalam Menangani Eksploitasi Seksual Komersial Anak di Indonesia. Journal of International Relations, 4(3), 536-546.

Mustika, R. (2017). Analisis Framing Pemberitaan Media Online Mengenai Kasus Pedofilia Di Akun Facebook. Jurnal Penelitian Komunikasi, 20(2). 138-148. https://doi.org/10.20422/jpk.v20i2.159

Rafiqa, A. L., \& Rani, F. (2015). Peran End Child Prostitution, Child Pornography and Trafficking of Children for Sexual Purposes (Ecpat) Internasional dalam Menanggulangi Kasus Child Trafficking di Albania (2007-2012). International Society, 2(2), 13-31.

Soesilo, R. (1991). Kitab Undang-Undang Hukum Pidana serta Komentarnya Pasal demi Pasal. Bogor: Politea.

Sulistyo, F., \& Manap, N. A. (2018). Pornography and Sexual Crimes towards Children in Indonesia: A Judicial Approach. Brawijaya Law Journal, 5(2), 261-270. http://dx.doi.org/10.21776/ub.blj.2018.005.02.09

Tianotak, N. (2011). Urgensi Cyberlaw Di Indonesia Dalam Rangka Penangan Cybercrime Disektor Perbanka. Jurnal Sasi, 17(4). 20-27. 


\section{Website}

Internet World Stats Usage And Population Statistic Retrieved from https://www.internetworldstats.com/stats3.html

Kementerian Perberdayaan Perempuan dan Perlindungan Anak Republik Indonesia. (2016). Press Release: Menteri PP dan PA : Indonesia Berkomitmen Hapuskan Kekerasan Seksual terhadap Anak Melalui Dunia Online. Retrieved from https://www.kemenpppa.go.id/index.php/page/read/29/115/pressrelease\%20menteri-pp-dan-pa-indonesia-berkomitmen-hapuskan-kekerasanseksual-terhadap-anak-melalui-dunia-online

UNICEF. (2017). UNICEF's approach to protection from sexual exploitation and abuse. Retrieved from https://www.unicef.org/protection/57929_96455.html 